\title{
Transposition
}

Musique et Sciences Sociales

\section{Multiple and Sustained Climaxes in Icelandic Post- Rock: For an Expansion of the Notion of Musical Climax}

Climax multiples et prolongés dans le post-rock islandais : pour une extension de la notion de climax musical

\section{Marion Brachet}

\section{OpenEdition}

Journals

\section{Electronic version}

URL: http://journals.openedition.org/transposition/5969

DOI: 10.4000/transposition.5969

ISSN: 2110-6134

Publisher

CRAL - Centre de recherche sur les arts et le langage

\section{Electronic reference}

Marion Brachet, "Multiple and Sustained Climaxes in Icelandic Post-Rock: For an Expansion of the Notion of Musical Climax", Transposition [Online], 9 | 2021, Online since 15 March 2021, connection on 23 April 2021. URL: http://journals.openedition.org/transposition/5969 ; DOI: https://doi.org/10.4000/ transposition.5969

This text was automatically generated on 23 April 2021.

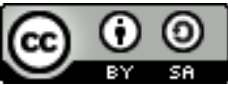

La revue Transposition est mise à disposition selon les termes de la Licence Creative Commons Attribution - Partage dans les Mêmes Conditions 4.0 International. 


\section{Multiple and Sustained Climaxes in Icelandic Post-Rock: For an Expansion of the Notion of Musical Climax}

Climax multiples et prolongés dans le post-rock islandais : pour une extension de la notion de climax musical

Marion Brachet

\section{Introduction}

1 The English word "climax", which refers to an orgasm, has been extended to any peak of intensity. Its use is especially common in musicology. This double meaning is not inconsequential: "climax" is usually kept for phenomena matching a restricted understanding of what an orgasm can be, a restriction induced by the prevalence of one standardized representation of cis male pleasure. The traditional musicological use of the word climax does fit classical/romantic climaxes and this typical view of the male orgasm insofar as it refers to a precise highpoint ${ }^{1}$ preceded by a crescendo and almost immediately followed by a tension fallout. Moreover, this outline is generally supported by a harmonic convergence, as a result of the tension-release dynamics structurally induced by the tonal system. Alternative climax templates, more fitting for a number of musical genres, could be drawn from more scrupulous reports of how orgasms are experienced, and not only by men. ${ }^{2}$

2 This association between musical classical forms, how they lead to climaxes, and a standardized male pleasure has famously been commented upon by Susan Mcclary. Analyzing a piece by Janika Vandervelde, she identifies what the composer thinks of as a female alternative to the supposedly male goal-oriented musical narrative. This musical alternative, as the author notes, "maps feminity onto [...] cycles and timeless 
stability", thus relying on biological essentialism. This matches a somewhat distorted understanding of female orgasm as an endlessly replicable phenomenon, as suggested in popular sonic representations of this pleasure such as Donna Summer's "Love to Love You Baby". ${ }^{3}$ A more nuanced view of what a female climactic model could sound like is presented by Esteban Buch, who embraces a reading of "[musical] climax as orgasm" in a Debussy piece while questioning potential male and female models - the latter displaying a hazier quality and, importantly, revitalizing the piece, while the former marks the end of the composition and abruptly fades to silence. ${ }^{4}$

3 This article aims at expanding the notion of musical climax, relying on the three types of orgasms identified and used in sexology: single (i.e. highpoint), multiple and sustained. ${ }^{5}$ Those categories, admittedly unevenly dispatched in gendered experiences, allow for a gender-neutral musical reading. Examples mainly drawn from Icelandic post-rock will be used to discuss multiple and sustained musical climaxes, using Brad Osborn's analysis on terminal climaxes as a starting point. ${ }^{6}$ This genre proves to be a relevant but certainly not exclusive example in such a discussion, as shown here by an additional extreme metal study case. Post-rock often relies on melodic and harmonic loops that go on in crescendo, thereby building from scratch extremely loud and saturated climaxes that can only be understood as sections. From a simple pattern, repetition is used as an opportunity to add more and more layers until the whole soundbox ${ }^{7}$ is full to breaking point, in a radical application of the accumulative technique observed by Mark Spicer. ${ }^{8}$ In this perspective, post-rock invites us to reshape and broaden our representations of what the notion of climax can cover.

4 The aim of this article is not to sexualize any musical climax and certainly not to say that every musical climax represents an orgasm, or that it cannot be understood without the reference to an actual orgasm. Such a view would take for granted the universality of the orgasmic experience and exclude the part of music listeners who, for any reason whatsoever, either do not have a sexual life or do not experience orgasms (at all, or in any conventional way). Consistently with this first point, this article does not respond to a Freudian framework, placing sexuality as the center of any aesthetic experience. I will therefore use the orgasm as an essentially formal reference in my analysis. Orgasms should be discussed in relation to musical climaxes so that male-oriented definitions are questioned and prevented from curbing the notion of musical climax.

\section{Human climaxes}

5 A first step towards a broader and more inclusive understanding of climaxes would be to take stock of the female orgasmic experience. The defense of a female sexual subjectivity has been a fundamental process in feminist theories aspiring to address the politics of female bodies. ${ }^{9}$ Accordingly, Simone de Beauvoir makes a point of giving an account of female pleasure and its apparent contrasts with the male one, relying on qualitative testimonies gathered among dozens of women:

What is certain is that coitus for man has a precise biological end: ejaculation. And certainly many other very complex intentions are involved in aiming at this end; but once obtained, it is seen as an achievement, and if not as the satisfaction of desire, at least as its suppression. On the other hand, the aim for woman is uncertain in the beginning and more psychic than physiological; she desires arousal and sexual pleasure in general, but her body does not project any clear conclusion 
of the love act: and thus for her coitus is never fully complete: it does not include any finality. Male pleasure soars [...]. Feminine pleasure ${ }^{10}$ radiates through the whole body [...]. Because no fixed goal is assigned to it, pleasure aims at infinity: nervous or cardiac fatigue or psychic satiety often limits the woman's erotic possibilities rather than precise satisfaction [...]. ${ }^{11}$

Beauvoir is cautious with the word "orgasm" when applied to women. In order to highlight the hazy, lasting and non-teleological quality of female pleasure, she generally opts for the word "jouissance", as in this extract. The rise of quantitative research on sexuality is what pushed the orgasm towards its current status, that is to say, as a form of quantifier or even quality criterion of the sexual act. This tendency is derived from studies that began in the middle of the twentieth century, and whose purpose was to rationalize pleasure. ${ }^{12}$ Alfred Kinsey, ${ }^{13}$ the very first to promote this view, and its most radical defender, thinks of sexuality as "a rational economy of orgasm production". ${ }^{14}$

7 However, most famous are William Masters and Virginia Johnson's experiments and their detailed results on cisgendered male and female orgasms. Despite the normative bias of their study, rooted in marital psychology, their quantitative data on the orgasmic phenomenon is still widely cited today in medical publications. While debunking the myth of a radical dissimilarity between male and female orgasm experiences and using the same markers to describe them (see ill. 1 and 2), Masters and Johnson insist on the different temporalities of male and female sexual responses.

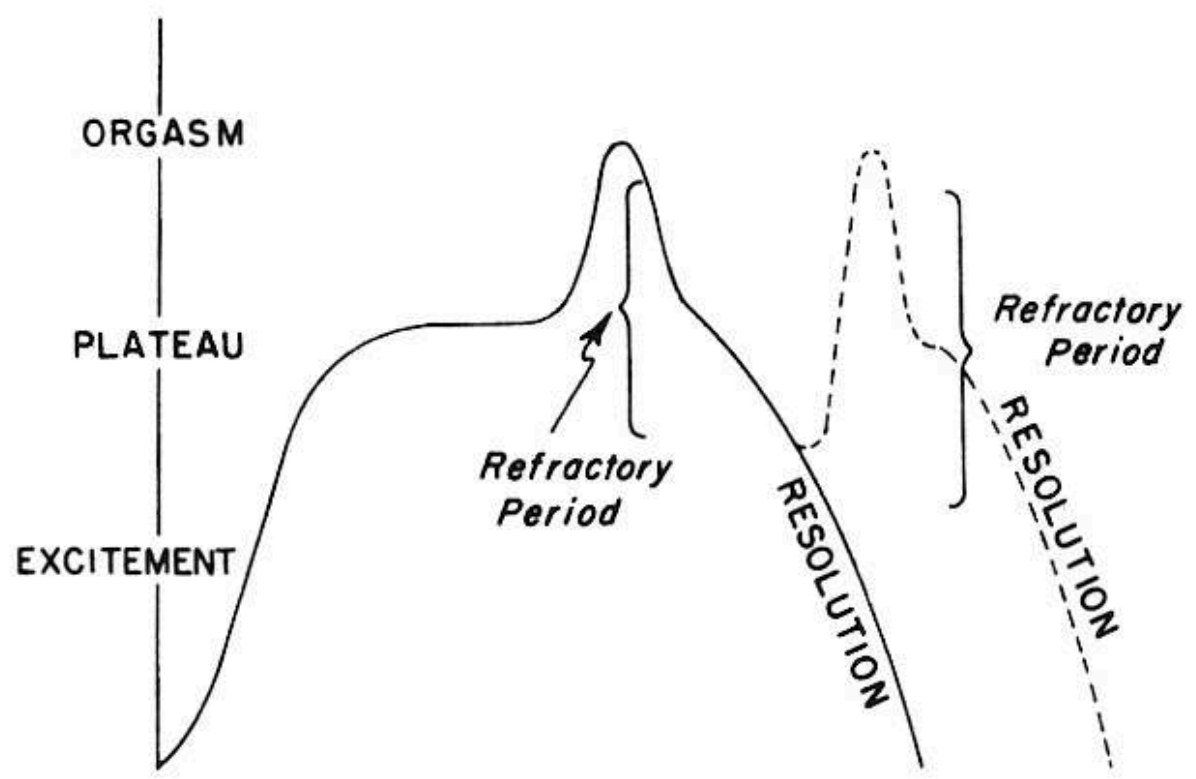

III. 1: Masters and Johnson's male sexual response cycle ${ }^{15}$ 


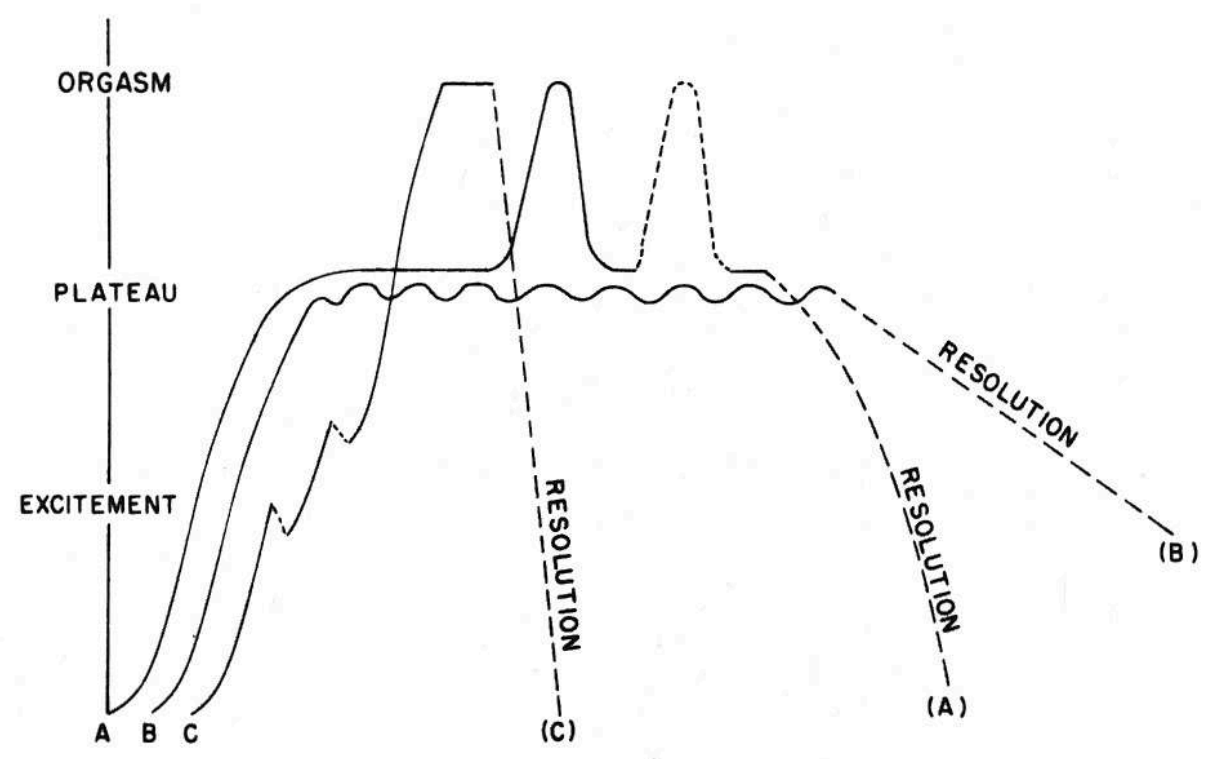

III. 2: Masters and Johnson's female sexual response cycle and Johnson's data fails to give a social account of orgasms, and to point out that sexual pleasure is "a gendered experience", where men's orgasms are consistently given primacy over women's. ${ }^{17}$ Recent numbers, also relying on cisgendered subjects exclusively, show that this discrepancy, or gender gap, is still significant, with $87 \%$ of men reporting an orgasm in their most recent sexual encounter, for only $63 \%$ of women. ${ }^{18}$ Even if the degree in which women's orgasms are "hindered by phallocentric imperatives" 19 is difficult to measure, it is important to remember that sex is not presocial $^{20}$, as some medical data may make it look, and that our understanding of orgasms should be "contextualized in all its manifestations, which involve the biological, psychological, and sociocultural spheres". ${ }^{21}$ While setting apart the role of each of those spheres in each situation is not easy, relying on data obtained from everyday experiences can help building more realistic orgasm scenarios, having to do with physiological reactions as much as gendered representations and expectations, which undoubtedly condition sexual responses and behaviors. ${ }^{22}$

In this perspective, many survey-based studies allowed other researchers to reshape Masters and Johnson's laboratory results. Three types of orgasms are now recognized: single, multiple and sustained. While the latter two are indeed more common among women, men can experience them as well, sometimes without a recalcitrant phase. ${ }^{23}$ Between $31 \%$ and $43 \%$ of women identify as multi-orgasmic, for only $8,7 \%$ of men. ${ }^{24} 13 \%$

Transposition, 9 | 2021 
of women and $8,4 \%$ of men claim having sustained orgasms, with durations spanning from over 15 seconds to even more than a minute..$^{25}$

11 In consequence of their greater frequency among women, these phenomena have been more extensively discussed in female cases than in male ones. Popular and mediaconveyed visions of female pleasure often seem to distort this data and the fact that "[female] orgasmic potential is undoubtedly restricted by fatigue" 26 and have often misunderstood replicability and possible prolonging for insatiability, or at least for elusiveness. This is compelling in numerous types of representations of women's pleasure, whether they are found in common beliefs,,$^{27}$ in popular sound, ${ }^{28}$ where "women's pleasure is elusive, questionable, and noisy", ${ }^{29}$ in pornography, where it is signaled by unreliable sounds, ${ }^{30}$ or even in romance novels, where it is still idealized ( $45 \%$ of depicted orgasms are simultaneous between the man and the woman, a very unrealistic proportion). ${ }^{31}$

\section{Orgasm and climax as an analytical category}

\section{Uses of the word "climax"}

12 Although they could promote alternative climactic models, most representations of female orgasms actually struggle to give a nuanced perspective on how they are experienced and thus prevent any accurate reshaping of the word "climax". A brief return to etymology and other uses of this word can be useful here. The scientific field which most uses this term is not musicology but ecology, where a climax is "the final stage of a biotic succession attainable by a plant community". ${ }^{32}$ Therefore, a climax ecosystem is a "steady-state system", used as a reference in ecological definitions of sustainability. ${ }^{33}$ During a climax period, some parameters have reached a (stable) peak, but these heightened parameters do not include increased tension - on the contrary. This definition is in sharp contrast with the traditional musicological one, where a climax is a momentaneous highpoint where all tensions converge before being released shortly afterwards. Nevertheless, other uses of the word "climax" do exist in musicology. In reference to rhetoric, a climax can point to "a figure of speech in which a series of phrases or sentences is arranged in ascending order of rhetorical forcefulness" ${ }^{34}$ In this case, the climax refers to the entire process, not just to the result of the crescendo.

13 While this conception is common in baroque or Renaissance musicology, where rhetoric's role in composition habits cannot be ignored, it is not dominant. Usual understandings of musical climaxes mostly derive from approaches such as Kofi Agawu's, who avoids using the word "climax" but still concentrates on what he calls "highpoints". ${ }^{35}$ Like Leonard Meyer, he takes into account several parameters in order to understand the structural role of these highpoints, but thinks of them as intelligible insofar as they converge to a single limited moment - which is consistent with how Western tonal art music progresses. Furthermore, in the classical and romantic paradigm, Meyer identifies two types of climaxes: statistical ones and syntactical ones. ${ }^{36}$ One way to put it would be to see the first as quantitative, since they are induced by things such as massive tutti or extreme registers, and the second as qualitative, since they rely on the musical language itself (for example, a key change). 
However, according to Austin Patty, "both Meyer and Kofi Agawu devote attention to musical climaxes and to the parameters that contribute to them but do not address the issue of interaction between musical parameters" ${ }^{37}$ Thanks to a careful study of these interactions, Patty makes the great contribution of expanding our understanding of musical climaxes to supposedly non-normative types of climaxes. A certain cliché consists in thinking of a musical climax as marked by a preceding acceleration, and a subsequent reduction of all parameters, such as rhythm, melody, harmony and speed. ${ }^{38}$ Patty opposes this view and makes the case that "acceleration and deceleration do not always produce tension and relaxation (respectively), but that pace changes interact with intensity changes to create unique energetic effects, categorized as pacing scenarios". ${ }^{39}$ This idea that different pacing scenarios lead to different energetic dynamics and therefore to different types of climaxes is essential to a better definition of this notion. Yet, even if Patty's typology opens the field of possible climaxes with new kinetic curves, it can only affect the perception of the temporality surrounding the highpoint, and not the actual temporality of the climax.

\section{Female orgasm and its sonic representations}

15 This idea of temporality is key in discussions involving music and sexual templates. In this regard, Robert Fink's comparison between disco and minimalism (insofar as they differ from tonal teleological art music) is illuminating. Against psychoanalysts and all those who claim that a repetitive economy always implies a death strive, he aims at identifying how "new experiences of desire and new experiments in musical form" are recombined in disco and minimalism. ${ }^{40}$ Besides observing historical, musical and reception similarities between disco and New-York minimalism, he inquires into their depiction of libido through musical form. He begins with a dismissal of Meyer's view that the opposition between teleology and anti-teleology should be absolute, advocating a "recombinant teleology", which avoids both the "phallic desire encoded by a Mahler symphony movement" and its "pure negation". Fink's main point is the need to "acknowledge the possibility of constructions of desire in repetitive music, however tantalizingly tantric or disturbingly insatiable". ${ }^{41}$ This is indeed a required passage if one wants to hear Donna Summer's "Love to Love You Baby" as a succession of more than twenty orgasms - as Fink does. Strangely, though, the author dismisses the model of female orgasm in his analysis, and conceives his recombinant teleology outside of any human sexual temporality.

Jon Stratton, on his part, has since underlined the inextricability of Donna Summer's seventeen-minute-long hit with the scientific and political changes surrounding the social representations of the female orgasm in the beginning of the '70s. It is precisely because Kinsey and Masters and Johnson made the general public grasp some measure of the female sexual response that "Love to Love You Baby" could even be conceived this way. Summer did not hesitate in confirming during interviews that the length of her song was a representation of female pleasure. ${ }^{42}$ That is not to say that this representation is unequivocal: Stratton notes that the "soft-core moans and sighs of 'Love to Love You Baby' can be read both as unconsummated female desire and, in a different register, as (almost) continuous orgasm" ${ }^{43}$ In any case, this points out that Fink's recombinant teleology might be too abstract for this example, and that the 
finding of musical equivalents to the female orgasm model as an alternative sonic climax is an actual issue.

This same problem is tackled by Susan McClary, who gives some insight into Janika Vandervelde's attempt to wrong-foot her listeners and their expectations in terms of form, desire and dynamics. ${ }^{44}$ The author claims that "tonal procedures strive to postpone gratification of [the need for the tonic's return] until finally delivering the payoff in what is technically called the 'climax', which is quite clearly to be experienced as metaphorical ejaculation". ${ }^{45}$ The way to climax, thus, would be a representation of a male orgasm. What would, instead, a female view sound like? In her composition Genesis II, Janika Vandervelde suggests an inversion of the usual roles of the so-called masculine and feminine themes.

According to conventions of musical narrative, it is the first item that gets to count as protagonist - the opening key, the characteristic initial theme [...]. And its narrative foil - the second ("feminine") theme/key - is generally more static: within the context of the protagonist's story it serves first as obstacle, then finally as that which is vanquished or absorbed.

But in Genesis II, the order is inverted. The aggressive strings are intruders into a musical landscape that had set up no expectation for change, no suggestion that a narrative was lying in wait. ${ }^{46}$

While the aggressiveness of the active narrative introduced by the strings is highlighted thanks to its unusual position in the musical form, we understand that the basis of the composition was, to the contrary, extremely static and repetitive: a few score excerpts in McClary's book confirm a series of very short cyclic patterns, producing the effect of clockwork.

I have had Vandervelde present Genesis II to several of my classes. Interestingly, many women students recognized in the clockwork an image of female erotic pleasure - pleasure that is not concerned with being somewhere else [...]. ${ }^{47}$

Vandervelde's bet suggests a firm stance: female pleasure is represented with total anti-teleology, as a continuous and calm reverie, whose virtually endless jouissance is rendered apparent by the out-of-place quality of the sudden strings. While it questions traditional contrasts in classical music, this composition might however "encourage essentialist readings" by "[mapping] feminity onto nature, cycles, and timeless stability" ${ }^{48}$ In spite of its differences with Fink's analysis, this work seems to head toward the same pitfall. First, the idea of female pleasure remains associated with a jouissance defined like the pure negation of teleological climaxes. Second, female pleasure ends up linked with passivity; not with replicable intensity curves, but with the absence of curves, with mere cycles dangerously rooting gender in biology.

Esteban Buch, relying on Debussy's "L'Isle joyeuse", offers another point of view on the matter ${ }^{49} \mathrm{He}$ focuses on a few bars Debussy added in a draft of this piece. The composer clarified: "these bars belong to Mada[me] Bardac [...] who dictated them to me", Emma Bardac being Debussy's new partner at the time of the writing..$^{50}$ These bars lead to a first climax halfway through the piece, the second one being more traditionally situated at the very end of the composition. The essential difference between these two climaxes is what follows them: intensity does not die down after the first one, whereas the second one is explosive and leads to silence. Buch cautiously suggests that these two climaxes could be linked to the protagonists, thus proposing they actually signal orgasms, since he hypothesizes that the temporalities, pacing and rhythms of these musical climaxes can allow them to be perceived as human climaxes..$^{51}$ The author 
wonders whether one could say that the first musical climax is a female orgasm, without giving an assured affirmative answer. Buch notes that Emma's desire is handled by the piece's structure, thus giving an idea of how a female climax model could be interpreted by a male composer. This first climax rises with a distinct suppleness, a rubato sensation, while much of the composition displays a "motoric" quality or even falls into dance patterns. It also comes within the context of intensity waves: "In this piece, the ascending movement keeps starting over and over, and the resolution of each wave is never the same twice". ${ }^{22}$ By contrast, the second climax gives its final purpose to the piece, which could confirm a link with a normative heterosexual script. While Buch's reliance on an actual relationship makes him take the leap between musical climax and musical orgasm, a leap that will not be taken in this article, one of his proposal's valuable contributions is to follow through on the temporalities and dynamics of plural climactic experiences using musicological analysis.

\section{Alternative climaxes in post-rock}

21 All of this existing literature tells us how the female orgasm, as the most studied form of alternative pleasure, is handled by composers in musical renderings of desire. While relying on these studies, my aim is, as stated earlier, slightly different: without denying the presence of a form of desire in music listening, I want to use orgasm and its plural forms as mere models in the reshaping of the musical understanding of the word "climax". To this end, I would like to expand Brad Osborn's approach, derived from his work on through-composed and terminally-climactic forms in recent rock music, where he notes that the most memorable and intense section of the songs tends to be deferred to the very end, in an autonomous and non-recapitulatory section, instead of being in the chorus like it used to be in rock music. ${ }^{53}$ My examples do not strictly fit his definition of terminally-climactic forms, and that is why I would like to compare them with his results, since we both focus on climactic sections and their role, within a comparable generic corpus. While relying on form, harmony, melody and rhythm, as well as technology and performance aspects, I will try to track climaxes and their effects, using the category of alternative climaxes, i.e. multiple and sustained climaxes, as opposed to single climaxes.

Post-rock is an almost readymade genre for highlighting the presence of such models in some rock areas. I chose to focus specifically on Icelandic post-rock, because one of today's most popular post-rock bands is Icelandic: a track by Sigur Rós will therefore occupy the greatest part of my analysis. One of the other reasons I want to insist on this national scene is its internal consistency. As Nicola Dibben points out, "ideas of Iceland as a wild landscape find expression in sonic aspects of the music". ${ }^{44}$ Former Sigur Rós member Kjartan Sveinsson adds: "the privilege to being [sic] an artist in Iceland... I think it's the space we have, not just the land". ${ }^{55}$ This imparts Icelandic post-rock with a singular connection with time and space, mainly rendered with an atmospheric quality in most compositions and a sensation of suspended temporality, as can be heard in my two main case studies, "Untitled \#8" by Sigur Rós and "Nárós" by Sólstafir. 


\section{Multiple climaxes}

23 My first example, by Sigur Rós, is officially called "Untitled \#8", but fans and band members alike have ironically nicknamed it "Popplagið” (the pop song). It is an 11'45 song, released as the closing track of the 2002 untitled album generally referred to as ( ), a symbol appearing on the front sleeve. Sigur Rós has closed all of its shows with this song for twenty years. An important characteristic of the ( ) album is its sung content, which is neither in Icelandic nor in English, but in a made-up non-signifying language.

Following Osborn, I will present "Untitled \#8" in formal groups, in turn divided into sections. This kind of dividing allows for a focus on the role of each group in relation to the climax of the song - a group being a unit whose thematic material is not repeated once the group is over. "Untitled \#8" is close to Osborn's two-part terminally climactic form (see ill. 3), while pushing it beyond its limits (see ill. 4).

\begin{tabular}{|l|l|}
\hline Verse/chorus group & Climactic group \\
\hline Intro, Verse 1, Chorus 1, Verse 2, Chorus 2 & Transition, Terminal Climax, Brief Outro \\
\hline
\end{tabular}

III. 3: Osborn's two-part terminally climactic archetype ${ }^{56}$

\begin{tabular}{|c|c|}
\hline \multirow[t]{2}{*}{ Verse/chorus group } & 00:00 Introduction \\
\hline & 01:49 Verse 1 \\
\hline & 03:10 Chorus 1 \\
\hline & 03:41 Transition \\
\hline & 04:07 Verse 2 \\
\hline & 05:29 Chorus 2 \\
\hline Climactic group & 06:06 Crescendo 1 \\
\hline & 07:38 Crescendo 2 \\
\hline & 09:26 First climactic section \\
\hline & 09:51 Counter-climax \\
\hline & $\begin{array}{l}\text { 10:09 Second climactic section } \\
\text { 10:09 Voice stage } \\
\text { 10:46 Guitar stage } \\
\text { 11:01 Keyboard stage }\end{array}$ \\
\hline & 11:23 Outro \\
\hline
\end{tabular}

III. 4: "Untitled \#8"'s form 

harmonic strategy is noteworthy, for it does not completely renounce the tensionrelease dialectics so common in tonal music. Admittedly, the whole of the climactic group boils down to a single $\mathrm{E}$ minor chord. However, this overall stability gives some increased importance to melodic details. The voice and the monodic guitar part hold an ostinato on the notes A4- C5-B4 for several minutes. This emphasis on the dominant degree keeps the listener on tenterhooks and insists on the tone that calls for a melodic resolution to the tonic, then present as a low pedal sound. That is why the arrival of the E5 on the guitar in the second stage of the second climactic section, reached with a bend from the natural seventh, feels like a modal version of the harmonic resolution so characteristic of classic "highpoint" climaxes. The wait for this high E lasts for three full minutes and allows this note to bring melodic relief. Moreover, this satisfaction is followed by the modal harmonic cadence I - bVII - bVI - I, which acts as a conclusive formula after five minutes of total harmonic stasis, especially since these chords are finally accompanied by the bass, previously stuck on the E pedal sound.

Besides this minimalist but conformist harmonic aspect, "Popplagið”'s climactic group actually works in unexpected ways. As already noted, it proceeds in stages. The first crescendo could be seen as the introduction of an excitement phase. The second crescendo settles in a static tension and could correspond to a plateau phase. The first climactic section, primarily marked by the drums exploding to a full kit cyclic pattern instead of just marking every beat on the toms, and by the guitars switching to typical post-rock quick alternate picking, is followed by a brief fallout supported by a rhythm change: I will call it the counter-climax, because it paves the way for a climactic comeback. This last section seems to overbid everything that had been heard before, all the more with each stage. Indeed, these three steps can only suggest a succession of climaxes, in addition to the first one starting at 9'26. In the second climax, the voice stage offers a new surge with the return of the looping drum pattern and Jónsi's high- 
pitched voice mixed louder than before and with strong resonance, exemplifying his unique rich-sounding falsetto technique. The guitar stage is the one bringing the longawaited E5, with the most reverberating note of the track, before the keyboard takes over, finally bringing full harmonic filling. This second climactic section thus ticks every box of a statistical climax, which could not be clearer on the song's waveform (see ill. 5), showing tremendous sound amplitude when the first climax begins at 9'26. One cannot help but notice that the intensity peak of this track lasts for two full minutes: the yellow saturation phase precisely matches the two climactic sections, with a minor setback during the counter-climax.

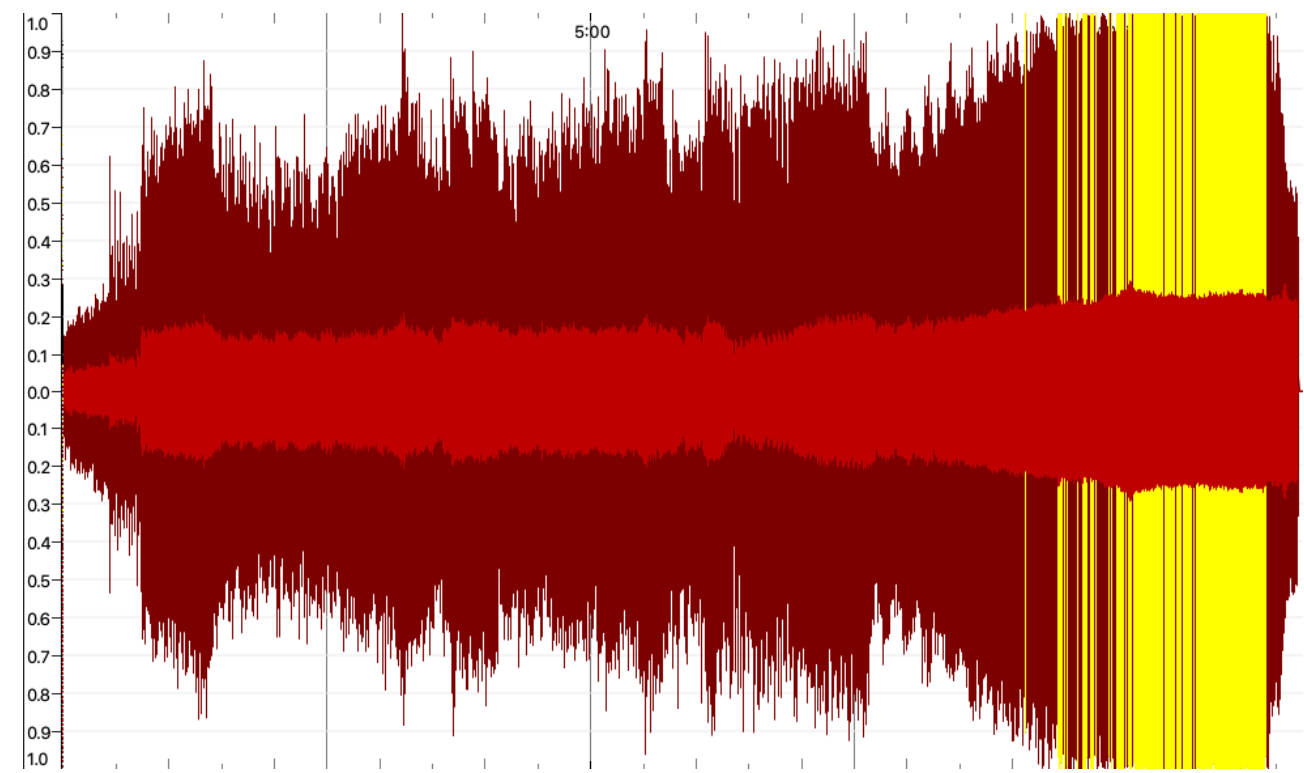

III. 5: "Untitled \#8"'s waveform ${ }^{59}$

Closer attention to what I called a counter-climax can inform the construction of this climactic group. This short section does not bring a full fallout of the tension, but rather a new impetus. The tools developed by Austin Patty, mentioned earlier, can help us understand this phenomenon. Here are the possible kinetic or energetic qualities Patty identified around a climax, qualities that depend on the pace of rhythmic, melodic and harmonic parameters, and on their position in relation to the climax.

\begin{tabular}{|l|l|l|}
\hline & Intensification phase & Descent phase \\
\hline Acceleration & Surge & Tumble \\
\hline Deceleration & Struggle & Settle \\
\hline
\end{tabular}

III. 6: Austin Patty's four main pacing scenarios ${ }^{60}$

30 While Patty works on a classical and romantic repertoire, the movement effects essential to these interactions remain relevant in "Untitled \#8". Both crescendos participate in the building of a "surge", since they contain a rise towards the high register and an intensification of all sound parameters. The counter-climax, however, is closer to Patty's "struggle", a dynamic which gives the impression that the climax is obtained through effort. The disappearance of the voice and cymbals, paired with the 
emphasis on the toms and the slowing down of the guitar brings this struggle effect, as if this pause in the midst of the climactic section was the sign of a difficulty to reach the next culminating phase. Yet, this struggle moment allows for an even more explosive new surge. This surge-struggle-surge succession is not normative and does not count among the usual climax scenarios identified by Patty. This originality fits a multiple climax scenario, where a first climax is reached after a long crescendo, and is followed by many others after a brief phase which allows one to breathe while desire is already getting back into motion. ${ }^{61}$

31 The saturation, confusion and logic of excess paradoxically ties this series of climaxes together, in what can only be understood as such with a definition of climax that includes the multiple orgasm template. Even if the high E does arrive at some point, nothing binds it to be reached at this exact moment: every other parameter could go on exploding again and again, and listening to "Untitled \#8", one cannot predict when the series of climaxes will be over, since the band always finds new ways to renew and intensify it. As Simone de Beauvoir would put it, this track "does not include any finality". That is a radical contrast with a classical or romantic musical climax: this type of culminating section does not bring a fully intelligible and recognizable relief, because even this relief is caught in a surge whose end cannot be predicted. It does not end with a tumble, nor with a fallout, nor with a logical conclusion. The outro only contains the fading resonant sounds of the guitar, its feedback, and eventually the sound of a jack being unplugged, dismissing the song's ending. The song stops in full saturation: the surge is brought to an end by exhaustion, not because an aim has been reached.

\section{Sustained climax}

Sólstafir's "Nárós" (2017), while also calling for an open-ended definition of climax, uses a different strategy. Sólstafir members have repeatedly acknowledged Sigur Rós' influence over them, and Berdreyminn (2017) decisively confirms an integration of postrock in their sound, but their musical background also lies in metal, which explains the presence of more straightforward sections in their songs, as well as some deviations from the inexorable crescendo form so common in post-rock. A brief recapitulatory section is indeed present at the end of "Nárós", which prevents it from fitting any of Osborn's formal archetypes.

\begin{tabular}{|l|l|}
\hline Soft group & $00: 00$ Introduction \\
\hline & $00: 21$ Verse 1 \\
\hline & $01: 25$ Instrumental verse \\
\hline & $02: 29$ Verse 2 \\
\hline Loud group & $02: 55$ Motoric atmosphere \\
\hline & $03: 23$ Verse A \\
\hline & $03: 50$ Motoric atmosphere \\
\hline
\end{tabular}




\begin{tabular}{|l|l|}
\hline & $04: 18$ Verse B \\
\hline & $04: 45$ Descending transition \\
\hline Climactic group & $05: 13$ Crescendo \\
\hline & $05: 40$ Climactic section 1 \\
\hline & $06: 08$ Climactic section 2 \\
\hline & $06: 35$ Counter-climax \\
\hline Loud group' & $06: 49$ Verse A' \\
\hline & $07: 16$ Conclusion \\
\hline
\end{tabular}

\section{7: "Nárós"'s form}

Once more, the triggering of the climactic group is fundamental. It is also preceded by a melodic and harmonic descent $(\mathrm{Ab}-\mathrm{Fm}-\mathrm{Cm}-\mathrm{Bb})$, allowing for a transition between the aeolian $\mathrm{C}$ mode of the soft and loud groups to the aeolian $\mathrm{G}$ mode of the crescendo. This descent does rely on the kind of sinking heard in "Untitled \#8"; nevertheless, a considerably more irradiant sound engages the climactic dynamic in "Narós". It does not start from scratch: instead, a completely different and brighter aura sets in thanks to the prominence of the melodic guitar in the mix, the long reverberation, and the sense of space induced by the low resolution of the guitar pedal sounds.

"Nárós" climaxes are not as explosive as "Popplagið”'s ones. In order to best understand them, it might be useful to remember the mechanics of an orgasm. It precisely happens when vasocontraction and muscular tension relax, which explains the relief accompanying it. ${ }^{62}$ Something similar happens in "Nárós". Rather than directly insisting on the sensorial confusion like Sigur Rós, Sólstafir's track places emphasis on such a feeling of release, of opening, while maintaining a continuous tension, essential to the extended temporality of the climax. Texture and rhythm are key in this strategy, which will be more apparent on spectrograms. 


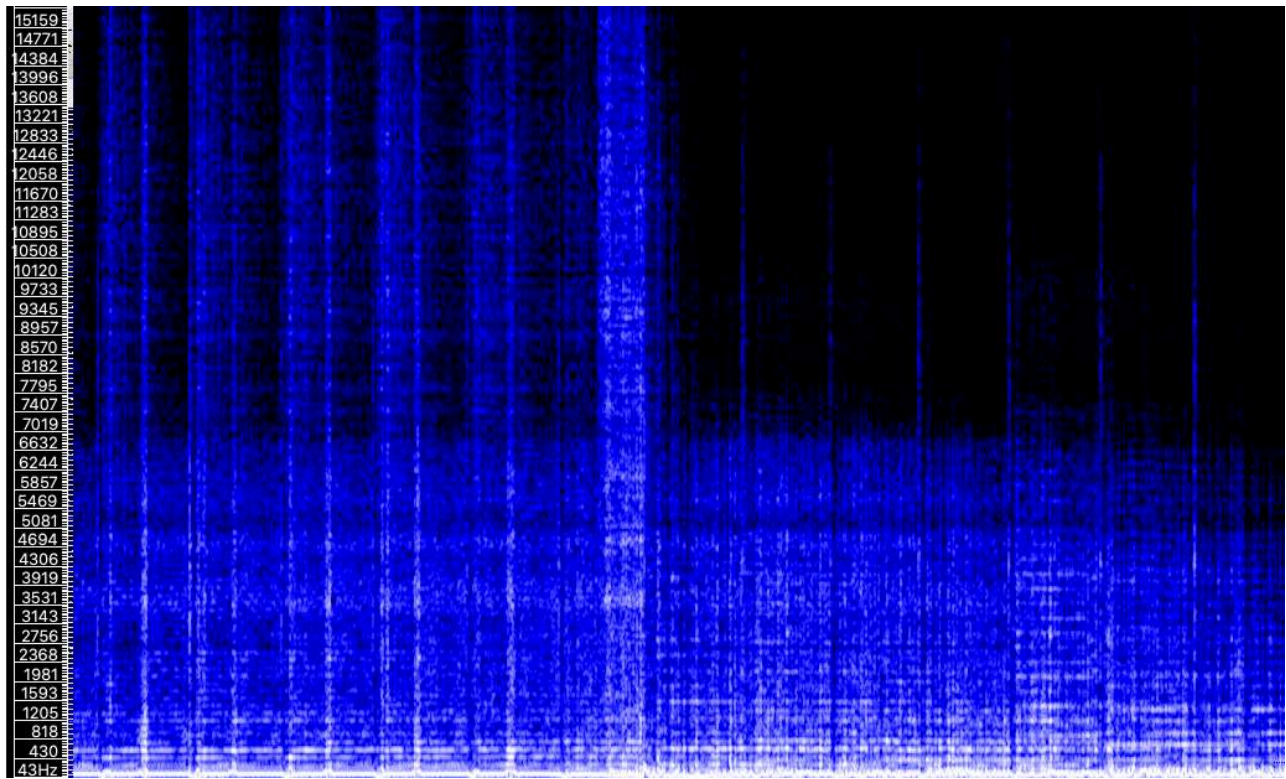

III. 8: "Nárós" spectrogram, beginning of the crescendo, 05'11-05’1663

First, the beginning of the crescendo distinguishes itself not only with the new mode it presents, but also thanks to its sudden clearness compared to the transition that precedes it (see ill. 8). While the snare drum and the open hi-hat cymbals were filling the soundbox ${ }^{64}$ during the transition, as can be seen on the resonance following each beat, the crescendo first relies on the bass drum only. This new accompaniment makes room for a refined introduction of the descending thirds pattern that prevails throughout the climactic group.

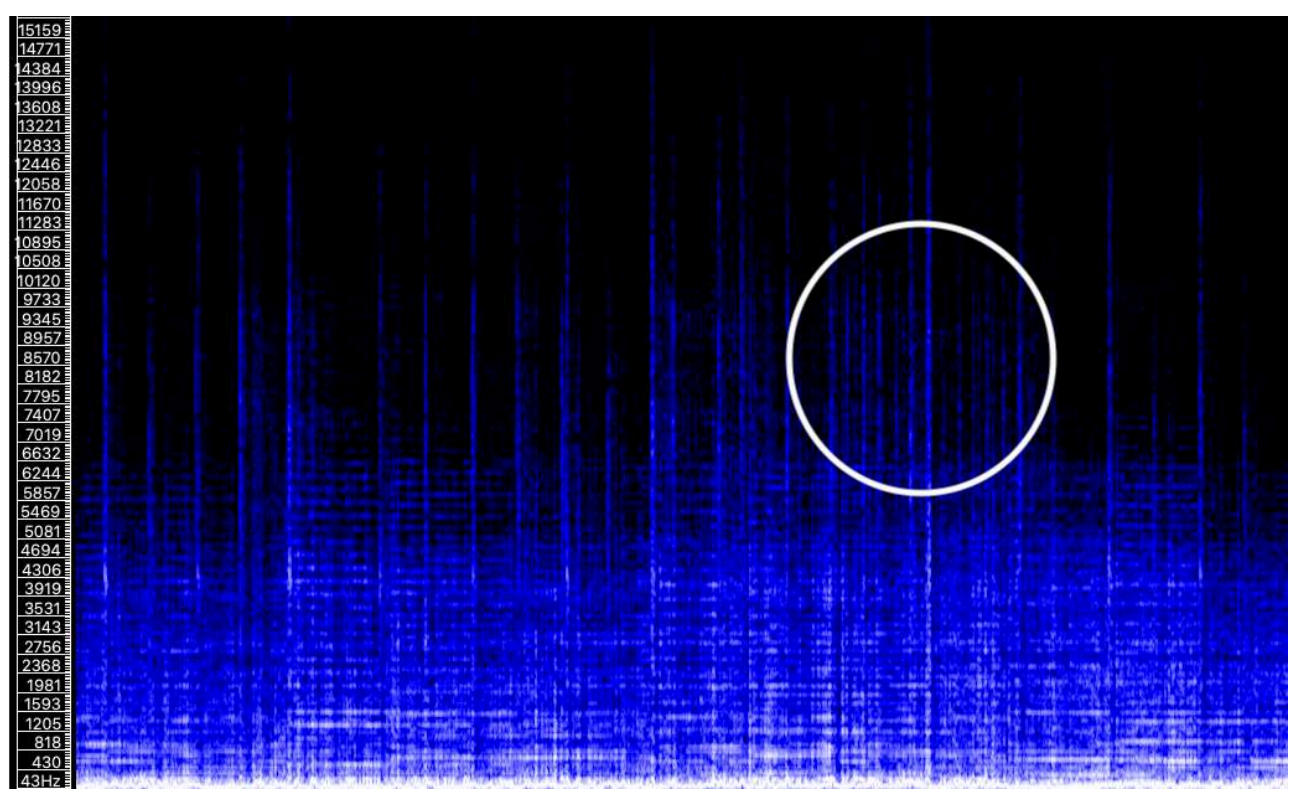

III. 9: "Nárós" spectrogram, crescendo, 05'31-05'34

Soon, the toms are also used in this crescendo section, mostly for driven off-beat fills at the end of the musical sentences (see ill. 9), and then for a hammering crescendo preceding the first stage of the climax. When the climactic section starts at $05^{\prime} 40$ (see ill. 10), drums settle on a stable pattern, simply marking every beat, the crash cymbals making a grand entrance that, combined with a high pedal sound played with full- 
range reverberation on the guitar with an E-Bow, tremendously open and clarify the general texture while densifying it, in what sure feels like a disorienting relief.

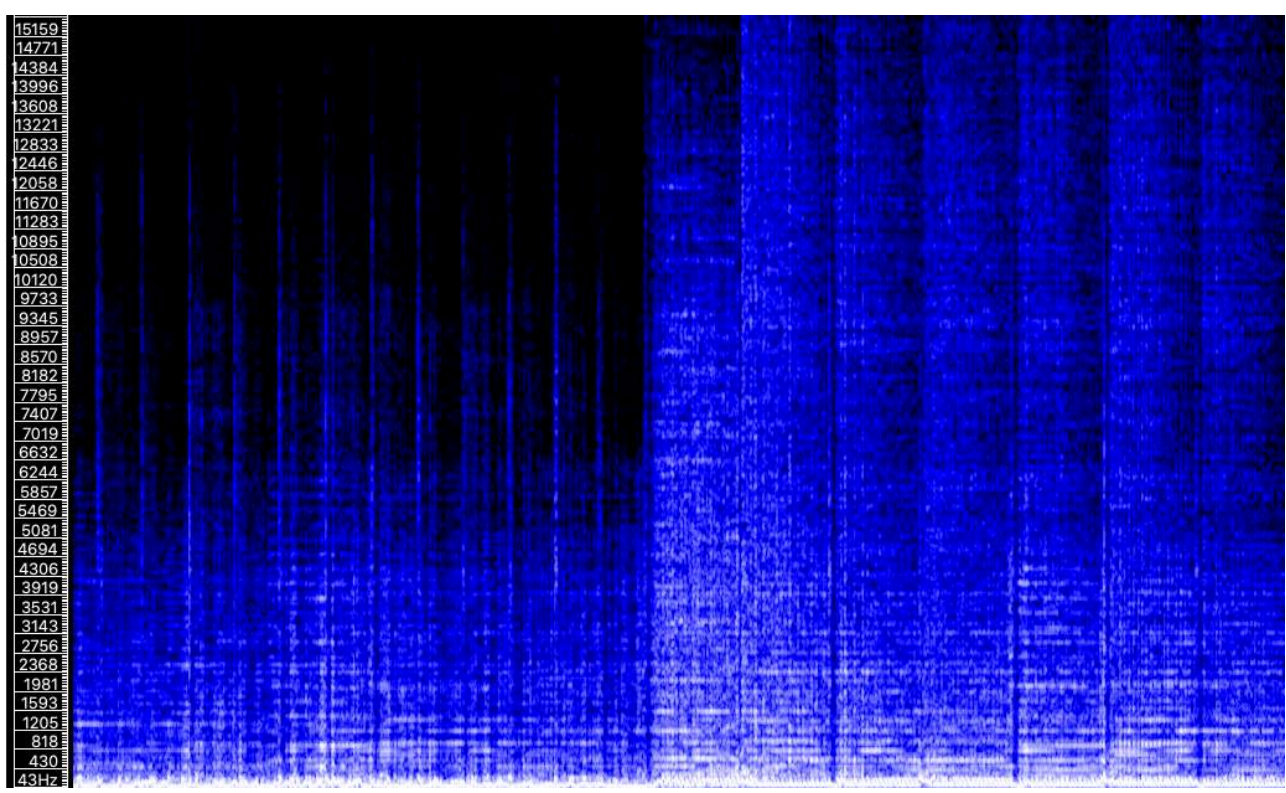

III. 10: "Nárós" spectrogram, beginning of the first climactic section 05'39-05'42

37 Even if the first impression is that of an opening comparable to the relaxing of muscular tension, the pedal sound immediately introduced actually evolves in a slow descending melodic line, progressing in slight delay with the actual rhythm of the song, thus bringing gradual dissonance to the instrumental ensemble. Reverberation increases during this first climactic section, and blurs the pedal sound played on the guitar with the keyboard layers, reinforcing the confusion and underlying tension. When this pedal sound has descended a major third, it comes back to its original high $G$, and stretches it even higher with a slow portamento, leading to the second climactic stage, thus beginning on an A flat (actually the third of an F minor chord). This new climax marks a return to the song's original aeolian C mode. Despite this syntactic step, the pedal sounds of the guitar and the keyboards continue to increase in volume and number, each pitch hazy and intertwined with the others, leading to an overwhelming quantity of sound sources in the stereo mix. This second climactic stage is entirely in keeping with the first one, and calls for a reading of the whole group as one sustained climax: it essentially pushes all of its parameters one step further, abandoning its original clarity for a heavier and fuller sound in every register (see ill.11), while maintaining the atmospheric quality so essential to Sólstafir's sound - and arguably to Icelandic post-rock sound. 


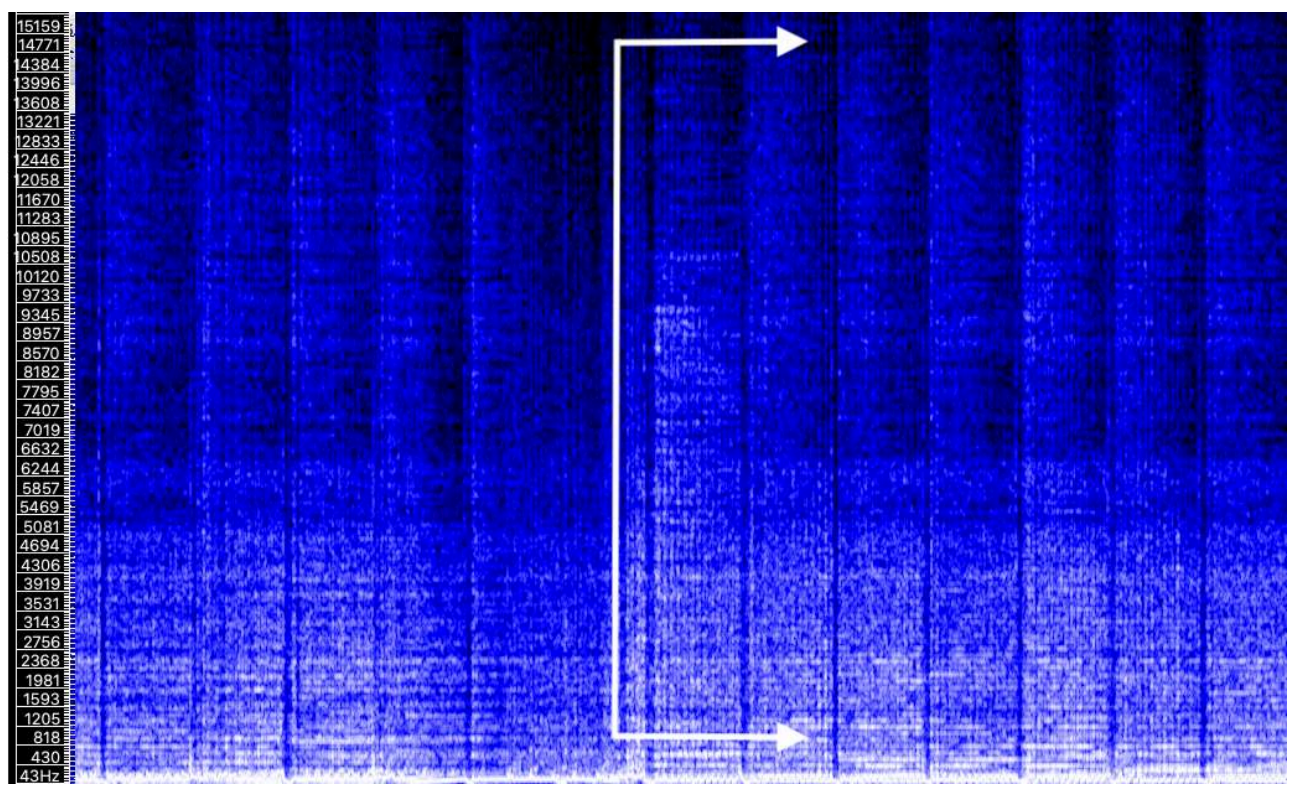

III. 11: "Nárós" spectrogram, transition between the first and second climactic section, 06'06-06'10

Once again, the climactic group slows down once exhaustion has been reached: no syntactic goal was fixed, and none has been reached. Surprisingly, one short verse returns after this, adding a recapitulative conclusion to the almost-terminal climax structuring the song.

The two scenarios I just commented upon, if they are to be considered climaxes (and I think their effects largely justify the fact that they should be), support the need for alternative templates to be integrated in our conceptions of musical climaxes. Not only are they syntactically autonomous sections in the tracks, like Osborn's terminal climaxes, they also keep on expanding thanks to statistical parameters allowing the listener to distinguish plural stages.

\section{Extreme spheres}

40 It should be noted that these alternative models are not limited to post-rock, even if this genre represents it best. Extreme metal bands, among others, also happen to resort to those extended, aimless final climaxes. One example could be "The Prolonging" (2010) by Swiss quartet Triptykon. This nineteen-minute-long song has very little harmonic readability, since the guitars and bass mostly play monodic riffs without harmonic fillings, on chromatic scales and in extremely low registers, where pitches become blurry. This blurriness undermines any feeling of harmonic progression. However, it could be argued that the track generally revolves around a B pole. This lack of legibility makes the two minutes non-autonomous terminal climax sound steady, even though its multiple guitar overdubs use both $\mathrm{F}$ natural and $\mathrm{F}$ sharp against the $\mathrm{B}$ bass. After fourteen minutes of chaotic formal progression with several returning sections and brutal riffs, the slow horizontal writing of the closing climactic section definitely makes it the most stable stage of the song, just like ecological climaxes. Its internal construction resembles the "Nárós" one, in that it proceeds by addition of layers becoming indiscernible one from another, in an overwhelming knot of slow melodic lines and pedal sounds. It would be difficult to say how many climactic steps it 
would contain - which proves how essential it is to think of this kind of segment as just one climactic group, or even one sustained climax.

\section{Conclusion}

41 Unlike most of the musical works discussed in the literature review, the tracks I commented upon cannot be seen as direct comparisons with human pleasure. No context would firmly support such an approach: "Untitled \#8" has no lyrics, "Nárós" tackles the bitterness from a relationship ended by the death of the loved one ${ }^{65}$, and "The Prolonging" talks about the destruction of a live being by a parasite. Nonetheless, their climactic structures show that including the manifold realities of orgasms in our common definition of a climax can help us build a more usable concept and have more versatile tools in order to understand the different kinds of climax we can actually hear in music. The climaxes heard in these few case-studies prove how a prolonged tension can be maintained and even increased through repetition. They may give us a teleological impression because of the inexorability they convey, but they return to the bodily frames of expanded climaxes by eventually fading in exhaustion. What is most striking is the expansiveness of their temporalities, and the resourcefulness of their thickening textures, vital to their active prolonging. This is how they contrast with Osborn's terminal climaxes: they are defined by their statistical excesses growing step by step and layer by layer throughout the sections even more than by their syntactical differences with what preceded them.

In post-rock and in metal, at the very least, multiple and sustained climaxes are common and should be studied as full-fledged climaxes - not only because they are integral to these genres' dynamics, but also because de-masculinized understandings of climaxes should be acknowledged in musicology. Multiple and sustained climaxes share the attributes of extended temporality, of replicability, i.e. possible repetitiveness, and consequently, of reduced teleology. The difference between these two templates, which have been brought together under the category of alternative climaxes for the purpose of this paper, can be subtle. The examples discussed in this article all contain more or less discernible plural stages: the distinction between the two models boils down to whether the contrasts between these stages justify the identification of multiple separated climaxes. If the final stages do not display much more than statistical reinforcement in comparison to the first ones, then chances are the climax will be perceived as a sustained one. If the song's form, as in "Untitled \#8", contains counterclimaxes or any setback in the climactic chain, as well as more syntactical contrasts between the climactic stages, then it more accurately fits a multiple climax model. Multiple and sustained climaxes have been called alternative in this paper insofar as they differ from what is traditionally identified as musical climax, that is to say the single climax, but it would be useful to insist on multiple and sustained climaxes as fullblown independent categories in future research. 


\section{BIBLIOGRAPHY}

AGAWU Kofi, “Structural 'Highpoints' in Schumann's Dichterliebe”, Music Analysis, vol. 3 no. 2, 1984, p. 159-180.

ANDREJEK Nicole and Tina FETNER, "The Gender Gap in Orgasms: Survey Data from a Mid-Sized Canadian City", International Journal of Sexual Health, vol. 31, no. 1, 2019, p. 26-35. DOI: 10.1080/19317611.2018.1563014

ARCos Barbara, "Female Sexual Function and Response", The Journal of the American Osteopathic Association, vol. 104, no. 1, 2004, p. 16-20.

BOzon Michel, Sociologie de la sexualité, Paris : Armand Colin, 2013 [2002].

BUCH Esteban, “Climax as Orgasm: On Debussy's 'L'isle joyeuse”, Music and Letters, vol. 100, no. 1, 2019, p. 24-60.

CABRERA Christine and MENARD Amy Dana, “'She exploded into a million pieces': a qualitative and quantitative analysis of orgasms in contemporary romance novel", Sexuality and Culture, vol. 17, no. 2, 2013, p. 193-212. DOI: 10.1007/s12119-012-9147-0

Colson Marie-Hélène, «L'orgasme des femmes, mythes, défis et controverses ", Sexologies, vol. 19, 2010, p. 39-47. DOI: 10.1016/j.sexol.2009.11.004

CORBETT John and KAPSALIS Terri, “Aural Sex: The Female Orgasm in Popular Sound”, The Drama Review, vol. 40, no. 3, 1996, p. 102-111.

DARLING Carol A., J. Kenneth DAVIDSON and Donna A. JENNINGS, “The Female Sexual Response Revisited: Understanding the Multiorgasmic Experience in Women", Archives of Sexual Behavior, vol. 20, no. 6, 1991, p. 531.

DE BEAUVOIR Simone, The Second Sex: Vol. II, New York/Toronto, Vintage Book Editions, 2011 [1949], p. 468-469. Translation by Constance Borde and Sheila Malovany-Chevallier.

DIBBEN Nicola, "Nature and Nation: National Identity and Environmentalism in Icelandic Popular Music Video and Music Documentary", Ethnomusicology Forum, vol. 18, no. 1, 2009, p. 131-151.

DUNN Marian E. and Jan E. TROST, "Male Multiple Orgasms: A Descriptive Study", Archives of Sexual Behavior, vol. 18, no. 5, 1989, p. 377-387.

FINK Robert, Repeating Ourselves: American Minimal Music as Cultural Practice, Berkeley, University of California Press, 2005.

FRANK Sarah E., "Intersex and Intimacy: Presenting Concerns About Dating and Intimate Relationships”, Sexuality and Culture, vol. 22, 2018, p. 127-147. DOI: 10.1007/s12119-017-9456-4

FRITH Hannah, “Accounting for Orgasmic Absence: Exploring Heterosex using the Story Completion Method", Psychology and Sexuality, vol. 4, no. 3, 2013, p. 310-322.

DOI: $10.1080 / 19419899.2012 .760172$

FRITH Simon, Performing Rites. On the Value of Popular Music, Cambridge, Harvard University Press, 1998 [1996].

GÉRARD M., M. BERRY, R.A. SHTARKSHALL, R. AMSEL and Y. M. BINIK, "Female Multiple Orgasm: An

Exploratory Internet-Based Survey", The Journal of Sex Research, 2020. DOI:

10.1080/00224499.2020.1743224 
GIAMI Alain, « De Kinsey au sida : l'évolution de la construction du comportement sexuel dans les enquêtes quantitatives ", Sciences sociales et santé, vol. 4, 1991, p. 23-55.

HANING R. Vernon, Stephen L. o'KEEFE, Keith W. BEARD, Elizabeth J. RANDALL, Martin J. KOMMOR and Sandra S. STROEBEL, "Empathic sexual responses in heterosexual women and men", Sexual and Relationship Therapy, vol. 23, no. 4, 2008, p. 324-344. DOI: 10.1080/14681990802326743 JACKSON Stevi and Sue ScOTT, "Embodying Orgasm: Gendered Power Relations and Sexual Pleasure", Women \& Therapy, vol. 24, no. 1-2, 2002, p. 99-220. DOI: 10.1300/J015v24n01_13 JOHNSON Bruce, "Introduction", JOHNSON Bruce (eds), Earogenous Zones: Sound, Sexuality and Cinema, London, Equinox, 2010, p. 1-11.

KINSEY Alfred, Sexual Behavior in the Human Female, Philadelphia, Saunders, 1953.

KINSEY Alfred C., POMEROY Wardell B. and MARTIN Clyde E., Sexual Behavior in the Human Male, Philadelphia, Saunders, 1948.

MARUCCIA Serena and Angela MAURIZI, “Anatomical and Physiological Description of Women's Sexuality", E. Costantini et al. (eds.), Female Sexual Function and Dysfunction, New York, Springer International Publishing, 2017, p. 7-25. DOI: 10.1007/978-3-319-41716-5_2

MASTERS William F. and JOHNSON Virginia E., Human Sexual Response, Boston, Little Brown, 1966. MCCLARY Susan, Feminine Endings: Music, Genre, Sexuality, Minneapolis, University of Minnesota Press, 1991.

MERTENS Wim, American Minimal Music: La Monte Young, Terry Riley, Steve Reich, Philip Glass, London, Kahn \& Averill, 1983.

MESTON Cindy M., Roy J. LEvin, Marca L. SIPSKI, Elain M. HULL and Julia R. HEIMAN, “Women's Orgasm", Annual Review of Sex Research, vol. 15, no. 1, 2004, p. 173-257. DOI: 10.1080/10532528.2004.10559820

MEYER Leonard, “Exploiting Limits: Creation, Archetypes, and Style Change”, Daedalus, vol. 109, no. 2, 1980, p. 177-205.

MEYER Leonard, Style and Music: Theory, History and Ideology, Philadelphia, University of Pennsylvania Press, 1989.

MOORE Allan F., Songs Means. Analysing and interpreting recorded popular song, Farnham/Burlington, Ashgate, 2012.

MOORE Allan F., "Patterns of Harmony”, Popular Music, vol. 11, no. 1, 1992, p. 73-106.

OSBORN Brad, "Understanding through-composition in post-rock, math-metal and other postmillennial rock genres", Music theory online, vol. 15, no. 3, 2011. https://mtosmt.org/issues/mto. 11.17.3/mto.11.17.3.osborn.pdf, visited on 7 May 2018.

OSBORN Brad, "Subverting the Verse/Chorus Paradigm: Terminally Climactic Forms in Recent Rock Music", Music Theory Spectrum, vol. 35, no. 1, 2013, p. 27-43.

PATTY Austin, "Pacing Scenarios: How Harmonic Rhythm and Melodic Pacing Influence our Experience of Musical Climax", Music Theory Spectrum, vol. 31, no. 2, 2009, p. 325-367.

PIEMONTE Jennifer L., Terri D. CONLEY, Staci GUSAKova, “Orgasm, Gender, and Responses to Heterosexual Casual Sex", Personality and Individual Differences, vol. 151, article 109487, 2019. DOI: $10.1016 /$ j.paid.2019.06.030 
SALISBURY Claire M. A. and William A. FISHER, “'Did You Come?' A Qualitative Exploration of Gender Differences in Beliefs, Experiences, and Concerns Regarding Female Orgasm Occurrence During Heterosexual Sexual Interactions", Journal of Sex Research, vol. 51, no. 6, 2014, p. 616-631.

DOI: $10.1080 / 00224499.2013 .838934$

SPICER Mark, “(Ac)cumulative Form in Pop-Rock Music”, Twentieth-Century Music, vol. 1, no. 1, 2004, p. 29-64. DOI: 10.1017/S1478572204000052

STRATTON Jon, “Coming to the Fore: The Audibility of Women's Sexual Pleasure in Popular Music and the Sexual Revolution", vol. 33, no. 1, 2014, p. 109-128. DOI: 10.1017/S026114301300055X

VILLARI Donata, “Sociocultural Considerations", E. Costantini et al. (eds.), Female Sexual Function and Dysfunction, New York, Springer International Publishing, 2017, p. 1-5.

DOI: $10.1007 / 978-3-319-41716-5 \_1$

WILLIAMs Linda, Screening Sex, Durham, Duke University Press, 2008.

WILLIS Malachi, Kristen N. JOZKOWSKI, Wen-Juo Lo and Stephanie A. SANDERS, “Are Women's Orgasms Hindered by Phallocentric Imperatives?”, Archives of Sexual Behavior, vol. 47, 2018, p. 1565-1576. DOI: $10.1007 / \mathrm{s} 10508-018-1149-\mathrm{z}$

\section{Discography}

Sigur Rós, (), FatCat, 2002.

Sólstafir, Beydreyminn, Season of Mist, 2017.

Triptykon, Eparistera Daimones, Century Media, 2010.

\section{NOTES}

1. AGAWU Kofi, “Structural 'Highpoints' in Schumann's Dichterliebe”, Music Analysis, vol. 3, no. 2, 1984, p. 159-180.

2. In this article, the terms "male" and "female" refer both to biological sex (genitalia and the orgasms they produce) and to gender as social and symbolic hierarchy (how these orgasms are experienced). In this perspective, "male" and "female" here relate to cisgendered persons.

3. STRATton Jon, "Coming to the Fore: The Audibility of Women's Sexual Pleasure in Popular Music and the Sexual Revolution, Popular Music, vol.33, no. 1, 2014, p. 109-128. DOI: 10.1017/ S026114301300055X

4. BUCH Esteban, "Climax as Orgasm: on Debussy's 'L'Isle Joyeuse”, Music and Letters, vol. 100, no. 1, 2019, p. 26-60.

5. HANING R. Vernon, Stephen L. O'KEEFE, Keith W. BEARD, Elizabeth J. RANDALL, Martin J. KOMMOR and Sandra S. STROEBEL, "Empathic sexual responses in heterosexual women and men", Sexual and Relationship Therapy, vol. 23, no. 4, 2008, p. 327. DOI: 10.1080/14681990802326743

MASTERS William H. and JOHNSON Virginia E., Human Sexual Response, Boston, Little Brown, 1966.

MESTON Cindy M., Roy J. LEVIN, Marca L. SIPSKI, Elain M. HULL and Julia R. HEIMAN, “Women's Orgasm", Annual Review of Sex Research, vol.15, no.1, 2004, p.173-257. DOI: 10.1080/10532528.2004.10559820

6. OSBORN Brad, "Understanding Through-Composition in Post-Rock, Math-Metal and Other PostMillennial Rock Genres”, Music Theory Online, vol. 15, no. 3, 2011. https://mtosmt.org/issues/mto. 11.17.3/mto.11.17.3.osborn.pdf, visited on 7 May 2018.

OSBORN Brad, "Subverting the Verse/Chorus Paradigm: Terminally Climactic Forms in Recent Rock Music", Music Theory Spectrum, vol. 35, no. 1, 2013, p. 27-43. 
7. MOORE Allan F., Song Means. Analysing and interpreting recorded popular song, Farnham/Burlington, Ashgate, 2012, p. 31: "[The soundbox] is a heuristic model of the way sound-source location works in recordings, acting as a virtual spatial 'enclosure' for the mapping of sources".

8. SPICER Mark, "(Ac)cumulative Form in Pop-Rock Music", Twentieth-Century Music, vol. 1, no. 1, 2004, p. 29-64. DOI: 10.1017/S1478572204000052

9. Colson Marie-Hélène, "L'orgasme des femmes, mythes, défis et controverses ", Sexologies, vol. 19, 2010, p. 41. DOI: 10.1016/j.sexol.2009.11.004

10. Jouissance in the original text.

11. DE BEAUVoIR Simone, The Second Sex: Vol. II, New York/Toronto, Vintage Book Editions, 2011 [1949], p. 468-469. Translation by Constance Borde and Sheila Malovany-Chevallier.

12. Bozon Michel, Sociologie de la sexualité, Paris, Armand Colin, 2002, p. 38.

13. KINSEY Alfred C., POMEROY Wardell B. and MARTIN Clyde E., Sexual Behavior in the Human Male, Philadelphia, Saunders, 1948.

KINSEY Alfred C., Sexual Behavior in the Human Female, Philadelphia, Saunders, 1953.

14. GIAMI Alain, «De Kinsey au Sida : l'évolution de la construction du comportement sexuel dans les enquêtes quantitatives ", Sciences sociales et sida, vol. 9, nº 4, 1991, p. 23-55.

15. Ill. 1 and ill. 2: MASTERS William H. and JOHNSON Virginia E., Human Sexual Response, p. 5.

16. MASTERS William H. and JOHNSON Virginia E., Human Sexual Response, p. 282-283.

17. ANDREJEK Nicole and Tina FETNER, "The Gender Gap in Orgasms: Survey Data from a Mid-Sized Canadian City", International Journal of Sexual Health, vol.31, no. 1, 2019, p. 33. DOI: $10.1080 / 19317611.2018 .1563014$

18. ANDREJEK Nicole and Tina FETNER, "The Gender Gap in Orgasms", p. 31.

19. WiLlis Malachi, Kristen N. JozKowsKi, Wen-Juo lo and Stephanie A. SANDERS, “Are Women's Orgasms Hindered by Phallocentric Imperatives?", Archives of Sexual Behavior, vol. 47, 2018, p. 1565-1576. DOI: 10.1007/s10508-018-1149-z

20. JACKSON Stevi and Sue scotT, "Embodying Orgasm: Gendered Power Relations and Sexual Pleasure", Women \& Therapy, vol. 24, no. 1-2, 2002, p. 99-220. DOI: 10.1300/J015v24n01_13

21. VILLARI Donata, "Sociocultural Considerations", E. Costantini et al. (eds.), Female Sexual Function and Dysfunction, New York, Springer International Publishing, 2017, p. 3. DOI: $10.1007 / 978-3-319-41716-5 \_1$

22. FRANK Sarah E., "Intersex and Intimacy: Presenting Concerns About Dating and Intimate Relationships", Sexuality and Culture, vol. 22, 2018, p. 127-147. DOI: 10.1007/s12119-017-9456-4

FRITH Hannah, "Accounting for Orgasmic Absence: Exploring Heterosex using the Story Completion Method", Psychology and Sexuality, vol.4, no.3, 2013, p.310-322. DOI: 10.1080/19419899.2012.760172

PIEMONTE Jennifer L., Terri D. CONLEY, Staci gusaKova, “Orgasm, Gender, and Responses to Heterosexual Casual Sex", Personality and Individual Differences, vol. 151, article 109487, 2019. DOI: $10.1016 /$ j.paid.2019.06.030

SALISBURY Claire M. A. and William A. FISHER, “'Did You Come?' A Qualitative Exploration of Gender Differences in Beliefs, Experiences, and Concerns Regarding Female Orgasm Occurrence During Heterosexual Sexual Interactions", Journal of Sex Research, vol.51, no. 6, 2014, p. 616-631. DOI: $10.1080 / 00224499.2013 .838934$

23. DunN Marian E. and Jan E. TROST, "Male Multiple Orgasms: A Descriptive Study", Archives of Sexual Behavior, vol. 18, no. 5, 1989, p. 377-387.

24. DARLing Carol A., J. Kenneth DAvidson and Donna A. JENnings, "The Female Sexual Response Revisited: Understanding the Multiorgasmic Experience in Women", Archives of Sexual Behavior, vol. 20, no. 6, 1991, p. 531.

HANING R. Vernon et al, “Empathic sexual responses”, p. 336.

25. Ibid. 
26. MARUCCIA Serena and Angela MAURIZI, “Anatomical and Physiological Description of Women's Sexuality”, E. costantini et al. (eds.), Female Sexual Function and Dysfunction, New York, Springer International Publishing, 2017, p. 21. DOI: 10.1007/978-3-319-41716-5_2

27. Piemonte Jennifer L. et al., "Orgasm, gender, and responses to heterosexual casual sex", p. 3.

28. What John Corbett and Terri Kapsalis study as "popular sound" in this context range from popular music and various sampling practices to phone sex recordings and other popular pornographic technologies.

CORBETT John and KAPSALIS Terri, “Aural Sex: The Female Orgasm in Popular Sound”, The Drama Review, vol. 40, no. 3, 1996, p. 102.

29. CORBETT John and KAPSALIS Terri, “Aural Sex”, p. 104.

30. wiLliams Linda, Screening Sex, Durham, Duke University Press, 2008. JoHnson Bruce, "Introduction", Earogenous Zones: Sound, Sexuality and Cinema, London, Equinox, 2010, p. 1-11.

31. CABRERA Christine and Amy Dana MENARD, “'She exploded into a million pieces': a qualitative and quantitative analysis of orgasms in contemporary romance novel", Sexuality and culture, vol. 17, no. 2, 2013, p. 193-212. DOI: 10.1007/s12119-012-9147-0

32. Encyclopedia Britannica, https://www.britannica.com/science/climax-ecology, visited on 12 February 2020.

33. HANNON Bruce, Matthias RUTH and Evan DELUCIA, "A physical view of sustainability", Ecological Economics, vol. 8, no. 3, 1993, p. 253-268.

34. Merriam-Webster Dictionary, https://www.merriam-webster.com/dictionary/climax, visited on 12 February 2020.

35. AGAWU Kofi, “Structural 'Highpoints' in Schumann's Dichterliebe".

36. MEYER Leonard, "Exploiting Limits: Creation, Archetypes and Style Change", Daedalus, vol. 109, no. 2, 1980, p. 177-205.

37. PATTY Austin, "Pacing Scenarios: How Harmonic Rhythm and Melodic Pacing Influence Our Experience of Musical Climax", Music Theory Spectrum, vol. 31, no. 2, 2009, p. 328.

38. MEYER Leonard, Style and Music: Theory, History and Ideology, Philadelphia, University of Pennsylvania Press, 1989, p. 209.

39. PATTY Austin, "Pacing Scenarios", p. 347.

40. FINK Robert, Repeating Ourselves: American Minimalist Music as Cultural Practice, Berkeley, University of California Press, 2005, p. 9.

41. FINK Robert, Repeating Ourselves., p. 40-47.

42. STRATTON Jon, "Coming to the Fore", p. 117.

43. Ibid.

44. MCCLARY Susan, Feminine Endings: Music, Gender, Sexuality, Minneapolis, University of Minnesota Press, 1991, p. 125.

45. Ibid.

46. Ibid.

47. Ibid.

48. MCCLARY Susan, Feminine Endings, p. 131.

49. BUCH Esteban, "Climax as Orgasm".

50. DEBussy Claude, Sketch [no.3] for L'Isle joyeuse, cited by BUCH Esteban, “Climax as Orgasm”, p. 28.

51. BUCH Esteban, “Climax as Orgasm”, p. 25.

52. BUCH Esteban, "Climax as Orgasm", p. 34.

53. OSBORN Brad, "Subverting the Verse/Chorus Paradigm".

54. DIBBEN Nicola, "Nature and Nation: National Identity and Environmentalism in Icelandic Popular Music Video and Music Documentary", Ethnomusicology Forum, vol. 18, no. 1, 2009, p. 136.

55. Cited in DIBBEN Nicola, "Nature and Nation", p. 138. 
56. OSBORN Brad, "Subverting the Verse/Chorus Paradigm", p. 30.

57. Moore Allan F., "Patterns of Harmony", Popular Music, vol. 11, no. 1, 1992, p. 83.

58. OSBORN Brad, "Subverting the Verse/Chorus Paradigm", p. 31-32.

59. This waveform has been created with Sonic Visualiser.

60. PATTY Austin, "Pacing Scenarios", p. 330.

61. GÉRARD M., M. BERRY, R. A. SHTARKSHALL, R. AMSEL and Y. M. BINIK, "Female Multiple Orgasm: An Exploratory Internet-Based Survey", The Journal of Sex Research, 2020. DOI: $10.1080 / 00224499.2020 .1743224$

62. MASTERS William F. and JOHNSON Virginia E., Human Sexual Response, p. 6.

63. These spectrograms have been created with Sonic Visualiser.

64. MOORE Allan F., Song Means.

65. I would like to thank Reddit users rafeind and haelaeif for their help in understanding the Icelandic lyrics.

\section{ABSTRACTS}

Effects produced by music and sex are similar insofar as they make us feel the present moment intensely (Frith 1996): this is probably the reason why our discourses frequently borrow vocabulary from the sexual lexical field when we want to name instants where our musical perception is most stimulated. The word "climax" is a transparent example, since it can literally refer to an orgasm, but is also used to talk about the intensity peak of a piece of music. This metaphor comes with unfortunate restrictions, in this case, the viewing of a climax as the equivalent of one standardized representation of male pleasure - the single orgasm. Yet, to see a musical climax as an intensity peak preceded by a crescendo and followed by an immediate fallout has its limits. It is generally relevant in tonal, classical music, but this outline loses its accuracy when it comes to other genre families, like rock music, which progresses step by step, and does not necessarily include one precise identifiable peak.

This article focuses on a post-rock corpus and shows the importance of a more flexible use of the notion of climax in musicology. The studied climaxes, shaped as long sections instead of one-time peaks, illustrate how musical analysis can benefit from alternative templates, namely those of multiple and sustained orgasms. Using these two models as formal references, and relying on Brad Osborn's work (2013), which evidenced the role of terminal climactic sections in recent rock music, this paper stresses the internal crescendos of the climactic sections often - but not exclusively - heard in post-rock. Their form, instrumentation, harmonic strategies, use of technology and performance highlight the main characteristics of these expanded climaxes: an extended temporality, replicability and reduced teleology.

Les effets causés par la musique et le sexe sont similaires en ce qu'ils nous font sentir le moment présent intensément (Frith 1996): c'est probablement la raison pour laquelle nos discours empruntent souvent du vocabulaire au champ lexical du sexe lorsque nous voulons mettre des mots sur les instants où notre perception musicale est la plus stimulée. Le mot «climax » est un exemple transparent, puisqu'en anglais il peut littéralement désigner un orgasme, mais est également utilisé pour parler du pic d'intensité d'une pièce musicale. Cette métaphore implique de regrettables limitations, par exemple la conception du climax comme l'équivalent d'une seule représentation standardisée du plaisir masculin - l'orgasme unique. Pourtant, voir un climax 
musical comme un pic d'intensité précédé d'un crescendo et immédiatement suivi d'une retombée a ses limites. Cette conception est généralement pertinente dans la musique classique tonale, mais ce profil de climax perd de sa justesse dans le cas d'autres familles génériques, telles que le rock, qui progresse pas à pas, et ne comporte pas nécessairement de point culminant précis et identifiable.

Cet article se concentre sur un corpus de post-rock afin de démontrer l'importance d'une utilisation plus souple de la notion de climax en musicologie. Les climax étudiés, qui prennent la forme de longues sections et non de pics d'intensité isolés, illustrent la manière dont l'analyse musicale peut bénéficier de modèles alternatifs, à savoir ceux des orgasmes multiples et prolongés. En mobilisant ces deux modèles en tant que références formelles et en s'appuyant sur le travail de Brad Osborn (2013), qui a mis en évidence le rôle des sections climactiques de fin de morceau dans la musique rock récente, cet article souligne les crescendos internes des sections climactiques que l'on entend souvent - mais pas exclusivement - dans le post-rock. Leur forme, leur instrumentation, leurs stratégies harmoniques, mais aussi leur utilisation des paramètres technologiques et performanciels mettent en lumière les principales caractéristiques de ces climax étendus: une temporalité allongée, la possibilité d'être renouvelés, et une faible téléologie.

\section{INDEX}

Mots-clés: rock, post-rock, metal, musique populaire, climax, forme, structure, musicologie, orgasme

Keywords: Rock, Post-Rock, Metal, Popular Music, Climax, Form, Structure, Musicology, Orgasm

\section{AUTHOR}

\section{MARION BRACHET}

Marion Brachet is a doctoral student in musicology at the EHESS - École des hautes études en sciences sociales (Paris, France) and Laval University (Québec City, Canada). She currently works as a teaching assistant at the EHESS. After a master's thesis about storytelling in progressive rock (EHESS, 2018), she is now working on a PhD thesis about narrativity in rock and folk music from the ' 60 s to the ' 80 s, with an emphasis on the link between narrativity and musical genres. Her research interests range from story songs to the reception of popular lyrics in general, as well as any musical factor able to inform the narrative and dynamics of a song. 